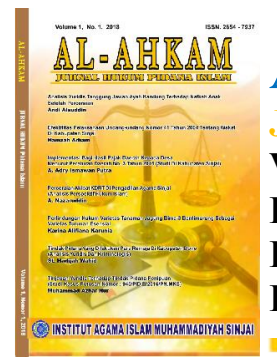

\title{
RIBA PERSPEKTIF SEJARAH DAN RELIGIUSITAS
}

\author{
Sapriadi $^{1}$, St. Hadijah Wahid ${ }^{2}$, Karina Alifiana Karunia ${ }^{3}$ \\ ${ }^{1}$ Institut Agama Islam Muhammadiyah Sinjai, Jl.Sultan Hasanuddin No.20, Kabupaten Sinjai \\ ${ }^{2}$ Institut Agama Islam Muhammadiyah Sinjai, Jl.Sultan Hasanuddin No.20, Kabupaten Sinjai \\ ${ }^{3}$ Institut Agama Islam Muhammadiyah Sinjai, Jl.Sultan Hasanuddin No.20, Kabupaten Sinjai \\ E-mail: sapriadi0487@gmail.com,Tlp:085210860232
}

\begin{abstract}
Abstrak
Eksistensi riba telah dikaji baik dalam tataran dunia akademik maupun pada kitab-kitab klasik. Akan tetapi, hingga saat ini praktik riba masih terjadi diberbagai aktivitas, baik dalam jual beli, hutang piutang, maupun transaksi-transaksi lainnya. Dengan demikian, riba membutuhkan penelaran khusus. Penelitian ini termasuk jenis penelitian kuantitaf, sedangkan spesifikasi penelitian ini adalah deskriptif analitis, yaitu penelitian yang menjelaskan keadaan yang terjadi, dengan tujuan untuk memunculkan fakta, yang diikuti dengan analisis, bertujuan untuk menemukan jawaban atas permasalahan riba. Pengumpulan bahan hukum dalam penulisan ini ditempuh dengan melakukan penelitian kepustakaan dan studi dokumen. Pendekatan utama yang ditempuh adalah interpretasi (sejarah dan religius). Berdasarkan dari hasil penelitian yang penulis lakukan dapat disimpulkan, bahwa Pandangan Islam, riba tidak hanya dipandang sebagai hal yang haram untuk dilakukan, akan tetapi merupakan perbuatan yang tidak memiliki moralitas bagi pelaku riba. Pelarangan melakukan praktik riba tidak hanya terjadi pada masa Islam, melainkan sebelum Islam agama lain seperti Yahudi dan Nasrani juga melarang pengambilan riba. Secara garis besar riba dikelompokkan menjadi dua yaitu: riba akibat hutang piutang dan riba akibat jual beli.
\end{abstract}

Kata Kunci : Riba, Perspektif Sejarah, Religuisitas.

\begin{abstract}
The existence of usury has been studied both in the academic world and in classical books. However, until now the practice of usury still occurs in various activities, both in buying and selling, accounts payable, and other transactions. Thus, usury requires special learning. This research is a quantitative type of research, while the specification of this research is descriptive analytical, namely research that explains the situation that occurs, with the aim of bringing out facts, followed by analysis, aiming to find answers to the problem of usury. The collection of legal materials in this writing is done by conducting library research and document studies. The main approach taken is interpretation (historical and religious). Based on the results of the research conducted by the author, it can be concluded that in the Islamic view, usury is not only seen as an unlawful thing to do, but is an act that has no morality for the perpetrator of usury. The prohibition of practicing usury did not only occur during the Islamic era, but before Islam, other religions such as Judaism and Christianity also prohibited the taking of usury. Broadly speaking, usury is grouped into two, namely: usury due to accounts payable and usury due to buying and selling.
\end{abstract}

Keywords: Riba, Historical Perspective, Religion. 


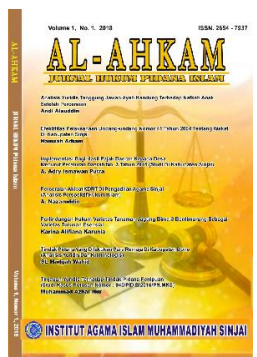

\section{Al-Ahkam}

Jurmal Hukum Pidana Islam

Volume 2, No. 2, 2020

ISSN (print) : 2654-7937

ISSN (online) : 2715-0313

Homepage : $\underline{\text { http://journal.iaimsinjai.ac.id/index.php/al-ahkam/index }}$

\section{Pendahuluan}

Aktivias perekonomian yang dilakukan oleh manusia untuk dikembangkan sebagai bentuk memenuhi kebutuhan hidup memiliki beberapa kaidah dan etika atau moralitas dalam menjalankan sesuai dengan syariat Islam. Allah SWT telah menurunkan rezeki ke dunia ini untuk dimanfaatkan oleh manusia dengan cara yang halal dan bersih dari segala perbuatan yang mengandung riba.

Pembahasan tentang riba baik dalam perkembangan pemikiran Islam maupun dalam peradaban Islam, karena riba merupakan permasalahan yang pelik dan sering terjadi pada masyarakat, hal ini disebabkan perbuatan riba sangat erat kaitannya dengan transaksitransaksi di bidang perekonomian yang sering dilakukan oleh manusia dalam aktivitas sehari-hari (Shalah ash-Shawi dan Abdullah al-Mushlih. hlm. 89-90).

Permasalah mengenai kedudukan riba dalam jual-beli maupun hutang-piutang sebenarnya tidak hanya dalam ajaran Islam saja. Tetapi agama diluar Islam seperti Yahudi dan Kristen juga mempunyai masalah dengan riba. Riba muncul tidak hanya pada masa pra Islam atau masa jahiliyah, namun riba telah menjadi persoalan yang serius jauh pada masa pada masa Yunani dan Romawi. Hanya saja di kalangan kedua dinasti tersebut riba menjadi pasang surut sesuai dengan keinginan penguasa pada waktu itu. Pada masa Romawi kuno yaitu sekitar abad V SM hingga IV SM, tedapat undang-undang yang membenarkan pengambilan riba dan pengambilan riba tersebut tidak boleh melebihi batas yang ditentukan oleh undang-undang tersebut. Pada masa Genucia (342 SM) kegiatan pengambilan riba atau bunga tidak diperbolehkan, tetapi pada Unciara (88 SM) praktik pengambilan bunga tersebut diperbolehkan kembali seperti semula (Muhammad Syafi'i Antonio, hlm. 44)

Terkait dengan pandangan yang berbeda tersebut, sangatlah penting untuk dipahami bahwa pengharaman riba tidak ada perbedaan diantara agama-agama. Semua agama samawi, seperti Hindu, Budha, Yahudi dan Nasrani juga melarang riba, walaupun pada tataran praktiknya banyak diabaikan. Akan tetapi, ada perbedaan terkait dengan makna riba dan transaksi.

Eksistensi riba dapat terjadi dari transaksi hutang piutang, namun bentuk dari sumber tersebut biasa berupa buyu, qardh dan lain sebagainya (Munawir, kamus ArabIndonesia, hlm. 1108). Ulama telah menetapkan dengan tegas dan jelas tentang pelarangan riba, disebabkan riba mengandung unsur eksploitasi yang dampaknya merugikan orang lain, hal ini mengacu pada al-Qur'an dan hadis serta ijma para ulama. Bahkan dapat dikatakan tentang pelarangannya sudah menjadi aksioma dalam ajaran agama Islam (Shalah ash-Shawi dan Abdullah al-Mushlih. hlm. 345.). Beberapa pemikir Islam berpendapat bahwa riba tidak hanya dianggap sebagai sesuatu yang tidak bermoral melainkan sesuatu yang menghambat aktifitas perekonomian masyarakat (Tim Pengembangan Syariah Institut Bankir Indonesia. hlm. 35).

\section{Metode}

1. Jenis Penelitian

Penelitian yang digunakan adalah penelitian pustaka (library research) dimana penelitian yang menekanka pada penelusuran dan penelaahan sumber-sumber tertulis dan bahan bacaan lain yang ada kaitannya dengan tema yang dibahas untuk selanjutnya dikaji dan ditelaah secara mendalam.

2. Sifat Penelitian

Sifat penelitian ini adalah deskriptif-analitik. Deskriptif adalah menjelaskan suatu gejala atau fakta untuk memberikan data-data dengan sangat teliti tentang gejala atau faktafakta tersebut (Sarjono Soekanto, Pengantar Penelitian Hukum. hlm. 10). Sedangkan analisis adalah sebuah usaha untuk mencari dan menata secara sistematis data-data 


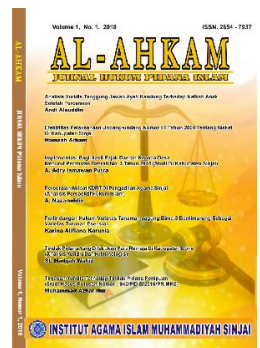

Al-Ahkam

Jurnall Hukum Pidana Islam

Volume 2, No. 2, 2020

ISSN (print) : 2654-7937

ISSN (online) : 2715-0313

Homepage : $\underline{\text { http://journal.iaimsinjai.ac.id/index.php/al-ahkam/index }}$

penelitian untuk kemudian dilakukan penelaahan guna mencari makna (Noeng Moehajir, Metode Penelitian Kualitatif. hlm. 104). Metode ini digunakan untuk menemukan jawaban atas permasalahan yang dimunculkan terhadap problematika yang ada sekaligus untuk menetapkan nilai dan status hukum persoalan tersebut.

3. Pendekatan Penelitian

Pendekatan masalah yang digunakan dalam penelitian ini adalah pendekatan historis dan teologis normatif dengan maksud untuk mengetahui konsep riba yang komprehensif.

4. Teknik Pengumpulan Data

Metode yang digunakan dalam teknik pengumpulan data pada penelitian ini adalah pengumpulan pustaka. Teknik pengumpulan data lewat pustaka yaitu menelusuri sumber data dari berbagai kitab dan karya ilmiah lainnya.

5. Analisis Data

Analisis data merupakan satu cara yang dipakai untuk menganalisis, mempelajari serta mengelola data tertentu sehingga dapat diambil suatu kesimpulan yang konkrit tentang persoalan yang diteliti dan dibahas. Dalam menganalisis data, penyusun menggunakan cara deduksi yaitu analisis yang berkaitan dari norma yang bersifat umum, kemudian ditarik menjadi kesimpulan yang bersifat khusus. Setelah terlebih dahulu dilakukan pengkajian atas data yang telah dikumpulkan, baik secara definitif maupun prinsip-prinsip yang terkandung di dalamnya. Dengan teori-teori yang ada, penyusun berusaha menganalisis dan merumuskan secara spesifik.

\section{Hasil dan Pembahasan}

\subsection{Definisi Riba}

Kata riba berasal dari bahasa Arab, secara etimologis berarti tambahan "alZiyadah", berkembang "al-Numuw", membesar "al-'uluw" dan meningkat "al-irtifa". Sehubungan dengan arti riba dari segi bahasa tersebut, ada ungkapan orang Arab kuno menyatakan sebagai berikut; "arba fulan 'ala fulan idza azada 'alaihi" (seorang melakukan riba terhadap orang lain jika di dalamnya terdapat unsur tambahan atau disebut "liyarbu ma a'thaythum min syai'in lita'khuzu aktsara minhu" mengambil dari sesuatu yang kamu berikan dengan cara yang lebih dari apa yang diberikan (Khoiruddin Nasution. h. 37).

Menurut terminologi ilmu fiqh, riba merupakan tambahan khusus yang dimiliki salah satu pihak yang terlibat tanpa adanya imbalan tertentu. Riba sering juga diterjemahkan dalam bahasa Inggris sebagai "usury" dengan arti tambahan uang atas modal yang diperoleh dengan cara yang dilarang oleh syara', baik dengan jumlah tambahan yang sedikit atau pun dengan jumlah tambahan banyak.

Riba identik dengan bunga atau rente, sering kita dengar di tengah-tengah masyarakat bahwa rente disamakan dengan riba. Pendapat itu disebabkan rente dan riba merupakan bunga uang, karena mempunyai arti yang sama maka hukumnya sama. Rente merupakan keuntungan yang diperoleh pihak bank atas jasanya yang telah meminjamkan uang kepada debitur dengan dalil untuk usaha produktif, sehingga dengan uang pinjaman tersebut usahanya menjadi maju dan lancar, dan keuntungan yang diperoleh semakin besar. Tetapi dalam akad kedua belah pihak baik kreditur maupun debitur sama-sama sepakat atas keuntungan yang akan diperoleh pihak bank.

Ibn a-Qayyim al-Jauziyyah, dalam Hendi Suhendi (2002), membagi riba menjadi dua, yaitu riba jalli (jelas) dan riba khafi (samar). Riba jalli adalah riba yang sangat terkenal di kalangan masyarakat Arab Jahiliyyah yang sangat memudharatkan terhadap kehidupan mereka dan dilarang secara tegas oleh al-Qur'an, yang dalam istilah lain disebut dengan 


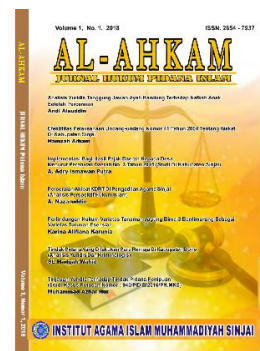

istilah riba nasiah. Riba nasiah adalah riba yang pembayarannya atau penukarannya berlipat ganda karena waktunya diundur. Sedangkan riba khafi adalah riba yang kurang dikenal dan diragukan keberadaannya di kalangan masyarakat Arab Jahiliyyah, yang dalam istilah lain disebut riba $a l-f a d l$. Riba $f a d h l$ adalah menjual sesuatu dengan alat tukar sejenis dengan adanya penambahan salah satunya tanpa tengang waktu, seperti menjual satu kilo gram gandum dengan dua kilo gram gandum (Hendi Suhendi, hlm. 61-62 ).

Eksistensi riba terbagi menjadi dua macam yaitu riba akibat dari hutang piutang yang telah dijelaskan tentang keharamannya dalam al- Qur'an, dan riba dari jual beli yang juga telah dijelaskan hukumnya dalam hadis.

a. Riba akibat hutang-piutang disebut riba qardh, yaitu suatu manfaat atau tingkat kelebihan tertentu yang diisyaratkan terhadap yang berhutang "muqtarid", dan riba jahiliyah, yaitu hutang yang dibayar dari pokoknya, karena si peminjam tidak mampu membayar hutangnya pada waktu yang ditetapkan (Muhammad Syafi'i Antonio. hlm. 77-78).

b. Riba akibat jual-beli disebut riba $f a d l$, yaitu pertukaran antar barang sejenis dengan kadar atau takaran yang berbeda dan barang yang dipertukarkan termasuk dalam jenis barang ribawi, dalam hadis Ubadah bin Shamit disebutkan bahwa Rasulullah SAW bersabda:

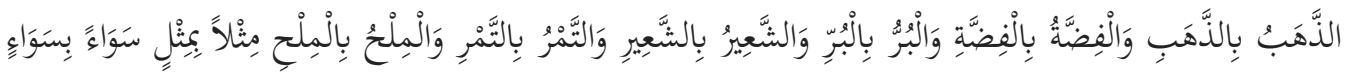

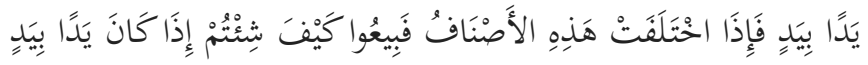

Artinya: "Jika emas dijual dengan emas, perak dijual dengan perak, gandum dijual dengan gandum, sya'ir (salah satu jenis gandum) dijual dengan sya'ir, kurma dijual dengan kurma, dan garam dijual dengan garam, maka jumlah (takaran atau timbangan) harus sama dan dibayar kontan (tunai). Jika jenis barang tadi berbeda, maka silakan engkau membarterkannya sesukamu, namun harus dilakukan secara kontan (tunai)." (HR. Muslim, no. 1587)

Dari Abu Sa'id Al-Khudri ra, Rasulullah Saw bersabda,

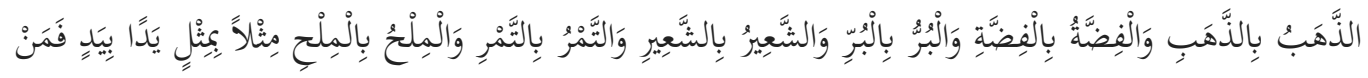

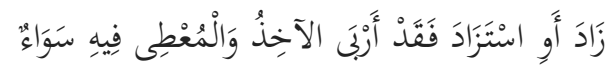

Artinya: "Jika emas dijual dengan emas, perak dijual dengan perak, gandum dijual dengan gandum, sya'ir (salah satu jenis gandum) dijual dengan sya'ir, kurma dijual dengan kurma, dan garam dijual dengan garam, maka jumlah (takaran atau timbangan) harus sama dan dibayar kontan (tunai). Barangsiapa menambah atau meminta tambahan, maka ia telah berbuat riba. Orang yang mengambil tambahan tersebut dan orang yang memberinya sama-sama berada dalam dosa." (HR. Muslim, no. 1584)

Subtansi hadits di atas adalah seseorang menukar barang berupa emas harus dengan emas pula yang sepadan dan beratnya juga harus sama, perak dengan perak dan harus diserahterimakan secara langsung. Dan riba nasi'ah, yaitu penangguhan atas penyerahan atau penerimaan jenis barang ribawi yang diperlukan dengan jenis barang ribawi lainnya. riba nasi 'ah muncul dan terjadi karena adanya perbedaan, perubahan, atau tambahan antara yang diserahkan saat ini maupun kemudian hari (HR.Ibnu Majah nomor, 2253-2254). 


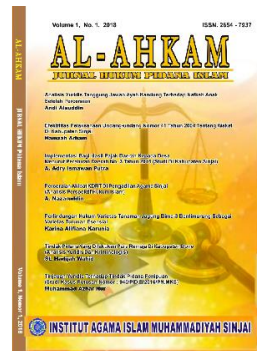

Al-Ahkam

Jurnal Hukum Pidana Islam

Volume 2, No. 2, 2020

ISSN (print) : 2654-7937

ISSN (online) : 2715-0313

Homepage : http://journal.iaimsinjai.ac.id/index.php/al-ahkam/index

Membedaan antara riba dan bunga diperlukan definisi. Secara leksikal, bunga sebagai terjemahan dari kata interest yang berarti tanggungan pinjaman uang, yang biasanya dinyatakan dengan persentase dari uang yang dipinjamkan (Muhammad. hlm. 35.). Jadi, uraian di atas dapat disimpulkan bahwa riba "usury" dan bunga "interest" pada hakikatnya sama, keduanya sama-sama memiliki arti tambahan uang.

Abu Zahrah dalam kitab Buhūsu fi al-ribā menjelaskan bahwa riba adalah tiap tambahan sebagai imbalan dari masa tertentu, baik pinjaman itu untuk dikonsumsi atau eksploitasi, artinya baik pinjaman itu untuk mendapatkan sejumlah uang guna keperluan pribadinya atau pinjaman itu untuk dikembangkan dengan mengeksploitasikan, karena nash itu bersifat umum (Muhammad Abū Zahrah. hlm. 38-39).

Abd al-Rahman al-Jaziri mengatakan para ulama sependapat bahwa tambahan atas sejumlah pinjaman ketika pinjaman itu dibayar dalam tenggang waktu tertentu adalaha riba (Abd ar-Rahman al-Jaziri. hlm. 245). Maksud tambahan adalah tambahan kuantitas dalam penjualan aset yang tidak boleh dilakukan dengan perbedaan kuantitas.

Riba erat kaitannya dengan dunia perbankan konvensional, di mana dalam perbankan konvensional banyak ditemui transaksi-transaksi yang memakai konsep bunga, berbeda dengan perbankan yang berbasis syariah yang memakai prinsip bagi hasil "mudharabah" sesuai dengan undang-undang perbankan syariah di Indonesia nomor 7 tahun 1992 (Undang -undang Perbankan. h. 44-45).

\subsection{Sejarah Riba}

Mekanisme riba telah dikenal serta diperaktekkan dalam transaksi-transaksi perekonomian oleh masyarakat Arab sebelum datangnya Islam. Akan tetapi pada zaman itu riba yang berlaku merupakan tambahan dalam bentuk uang akibat penundaan pelunasan hutang. Dengan demikian, riba dapat diartikan sebagai pengambilan tambahan dalam transaksi jual beli maupun hutang piutang secara batil atau bertentangan dengan kaidah syari'at Islam.

Riba tidak hanya dikenal dalam Islam saja, tetapi dalam agama lain riba telah kenal dan juga pelarangan atas perbuatan pengambil riba, bahkan pelarangan riba telah ada sejak sebelum Islam datang.

a. Riba pada Masa Jahiliyah

Pada pada masa Jahiliyah riba mempunyai beberapa bentuk aplikatif. Beberapa riwayat menceritakan riba jahiliyah.

Bentuk pertama; Riba Pinjaman, yaitu yang direfleksikan dalam satu kaidah di masa Jahiliyah: "tangguhkan hutangku, aku akan menambahkanya". Maksud kaidah tersebut adalah jika ada seseorang mempunyai hutang (debitur), tetapi ia tidak dapat membayarnya pada waktu jatuh tempo, maka ia (debitur) berkata: tangguhkan hutangku, aku akan memberikan tambahan. Penambahan itu bisa dengan cara melipat gandakan uang atau menambahkan umur sapinya jika pinjaman tersebut berupa binatang, demikian seterusnya (Shalah ash-Shawi dan Abdullah al-Mushlih. hlm. 350).

Menurut Qatadah yang dimaksud riba adalah orang Jahiliyah adalah seorang lakilaki menjual barang sampai pada waktu yang ditentukan. Ketika tenggang waktunya habis dan barang tersebut tidak berada di sisi pemiliknya, maka ia harus membayar tambahan dan boleh menambah tenggatnya (Syeikh Abul A'la al-Maududi. hlm. 114). Abu Bakar alJashshash berkata: riba dimasa Jahiliyah hanyalah sebuah pinjaman dengan rentang waktu, disertai tambahan tertentu. Tambahan itu adalah ganti dari rentang waktu.

Menurut Mujahid, menjelaskan tentang riba yang dilarang oleh Allah SWT. pada masa Jahiliyah, seseorang mempunyai piutang dari orang lain. Orang itu berkata kepadamu 


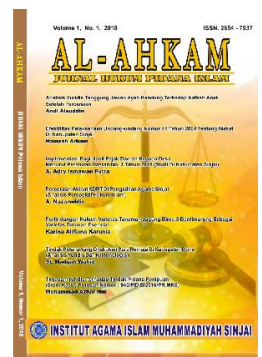

seperti itulah anda menangguhkannya dari saya, maka diampuni yang menangguhkannya" (Tafsir Ibnu Jarir III/67, VI/8).

Bentuk kedua; Pinjaman dengan pembayaran tertunda, tetapi dengan syarat harus dibayar dengan bunga.

Al-Jassash menyatakan, Riba yang dikenal dan biasa dilakukan oleh masyarakat Arab adalah berbentuk pinjaman uang dirham atau dinar yang dibayar secara tertunda dengan bunganya dengan jumlah sesuai dengan jumlah hutang dan sesuai dengan kesepakatan bersama (Shalah ash-Shawi dan Abdullah al-Mushlih. hlm. 351).

Bentuk ketiga; Pinjaman berjangka dan berbunga dengan syarat dibayar perbulan.

Ibnu Hajar al-Haitami menyatakan, Riba nasi'ah adalah riba yang populer di masa Jahiliyah. Karena biasanya, seseorang meminjamkan uang kepada orang lain dengan pembayaran tertunda, dengan syarat ia mengambil sebagian uangnya setiap bulan sementara jumlah uang yang dihutang tetap sampai tiba waktu pembayaran. Kalau tidak mampu melunasinya, maka diundur dan ia harus menambah jumlah yang harus dibayar.

b. Riba Pada Masa Yunani Kuno

Bangsa Yunani kuno mempunyai peradaban tinggi, peminjaman uang dengan memungut bunga dilarang keras. Ini tergambar pada beberapa pernyataan Aristoteles yang sangat membenci pembungaan uang.

"Bunga uang tidaklah adil"

"Uang seperti ayam betina yang tidak bertelur"

"Meminjamkan uang dengan bunga adalah sesuatu yang rendah derajatnya" (Gedung Pusat Pengembangan Islam. hlm. 11).

c. Riba pada Masa Romawi

Kerajaan romawi melarang setiap jenis pemungutan bunga atas uang dengan mengadakan peraturan-peraturan keras guna membatasi besarnya suku bunga melalui undang-undang. Kerajaan Romawi adalah kerajaan pertama yang menerapkan peraturan guna melindungi para peminjam.

\section{Riba Perspektif Religiusitas}

a. Pandangan Agama Yahudi

Pelarangan praktik riba dalam agama Yahudi termaktub dalam kitab sucinya, menurut kitab suci agama Yahudi yang disebutkan dalam Perjanjian Lama kitab keluaran ayat 25 pasal 22: "Bila kamu menghutangi seseorang diantara warga bangsamu uang, maka janganlah kamu berlaku laksana seorang pemberi hutang, jangan kamu meminta keuntungan padanya untuk pemilik uang"( Karnaen Purwaatmaja. hlm. 37). Dan pada pasal 36 disebutkan: " Supaya ia dapat hidup di antaramu janganlah engkau mengambil bunga uang atau riba dari padanya, melainkan engkau harus takut akan Allahmu, supaya saudaramu dapat hidup diantaramu".

Akan tetapi orang Yahudi berpendapat bahwa riba itu hanyalah terlarang kalau dilakukan dikalangan sesama Yahudi, dan tidak dilarang dilakukan terhadap kaum yang bukan Yahudi. Mereka mengharamkan riba sesama mereka tetapi menghalalkannya kalau pada pihak yang lain. Dan inilah yang menyebabkan bangsa Yahudi terkenal memakan riba dari pihak selain kaumnya. Berkaitan dengan kezaliman kaum Yahudi, Allah SWT berfirman dalam al-Qur'an surat al-Nisa' ayat 160-161 secara tegas menyatakan bahwa perbuatan riba atau memakan harta orang lain dengan jalan batil, dan Allah akan menyiksa mereka dengan siksaan yang pedih. 


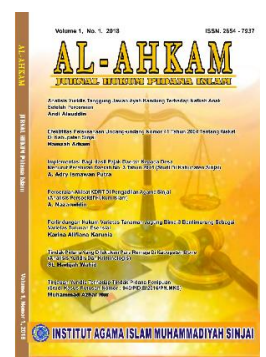

Al-Ahkam

Jurnall Hukum Pidana Islam

Volume 2, No. 2, 2020

ISSN (print) : 2654-7937

ISSN (online) : 2715-0313

Homepage : $\underline{\text { http://journal.iaimsinjai.ac.id/index.php/al-ahkam/index }}$

\section{b. Pandangan Agama Nasrani}

Berbeda dengan orang Yahudi, umat Nasrani memandang riba haram dilakukan bagi semua orang tidak terkecuali siapa orang tersebut dan dari agama apapun, baik dari kalangan Nasrani sendiri ataupun non-Nasrani. Menurut mereka (tokoh-tokoh Nasrani) dalam perjanjian lama kitab Deuntoronomy pasal 23, pasal 19 disebutkan: "Janganlah engkau membungakan uang terhadap saudaramu baik uang maupun bahan makanan atau apapun yang dapat dibungakan" (Gedung Pusat Pengembangan Islam. hlm. 11). Kemudian dalam perjanjian baru di dalam Injil Lukas ayat 34 disebutkan: "Jika kamu menghutangi kepada orang yang engkau harapkan imbalannya, maka di mana sebenarnya kehormatan kamu. Tetapi berbuatlah kebaikan dan berikanlah pinjaman dengan tidak mengharapkan kembalinya, karena pahala kamu sangat banyak" (Muhammad. hlm. 39).

Pengambilan bunga uang dilarang gereja sampai pada abad ke-13M. pada akhir abad ke-13 timbul beberapa faktor yang menghancurkan pengaruh gereja yang dianggap masih sangat konservatif dan bertambah meluasnya pengaruh mazhab baru, maka piminjaman dengan dipungut bunga mulai diterima masyarakat. Para pedagang berusaha menghilangkan pengaruh gereja untuk menjustifikasi beberapa keuntungan yang dilarang oleh gereja. Ada beberapa tokoh gereja yang beranggapan bahwa keuntungan yang diberikan sebagai imbalan administrasi dan kelangsungan organisasi dibenarkan karena bukan keuntungan dari hutang. Tetapi, sikap pengharaman riba secara mutlak dalam agama Nasrani dengan gigih ditegaskan oleh Martin Luther, tokoh gerakan Protestan. Ia mengatakan keuntungan semacam itu baik sedikit atau banyak, jika harganya lebih mahal dari harga tunai tetap riba (Gedung Pusat Pengembangan Islam. hlm. 12).

\section{c. Pandangan Agama Islam}

Sejak zaman Nabi Muhammad SAW, riba telah dikenal pada saat turunnya ayatayat yang menyatakan larangan terhadap transaksi yang mengandung riba sesuai dengan masa dan periode turunnya ayat tersebut sampai ada ayat yang melarang dengan tegas tentang riba. Bahkan istilah dan persepsi tentang riba begitu mengental dan melekat di dunia Islam. Oleh karena itu, terkesan seolah-olah doktrin riba adalah khas agama Islam. Akan tetapi menurut seorang Muslim Amerika, Cyril Glasse, dalam buku ensiklopedinya, tidak diberlakukan di negeri Islam modern manapun. Sementara itu, kebanyakan orang tidak mengetahui bahwa di agama Kristen pun, selama satu melenium, riba adalah barang terlarang dalam pandangan theolog, cendikiawan maupun menurut undang-undang yang ada.

Kegiatan transaksi yang mengandung riba merupakan kegiatan transaksi yang secara tegas diharamkan bahkan pengharamannya telah menjadi aksioma dalam ajaran Islam. Riba merupakan transaksi yang mengandung unsur eksploitasi terhadap para peminjam (debitur) bahkan merusak akhlak dan moralitas manusia. Pengharaman ini tidak hanya berlaku pada agama Islam saja, akan tetapi dalam agama-agama samawi juga melarangnya bahkan mengutuk pelaku riba. Plato (427-347 SM) misalnya, termasuk orang yang mengutuk para pelaku pelipat gandaan uang (Muhammad. hlm. 35).

Sedikit atau banyaknya riba, memang masih menjadi perdebatan, hal ini dikerenakan bahwa riba Jahiliyah yang dengan jelas dilarangnya riba adalah yang berlipat ganda (ad'afan mudha'afah). Landasan dari riba dalam al-Qur'an surat al-Imran ayat 130:

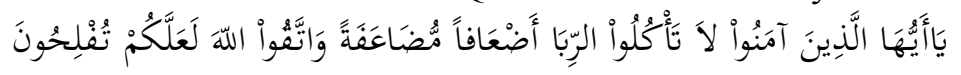

Terjemahannya: "Hai orang-orang yang beriman, janganlah kamu memakan riba berlipat ganda dan bertakwalah kamu kepada Allah supaya kamu mendapatkan keberuntungan" 


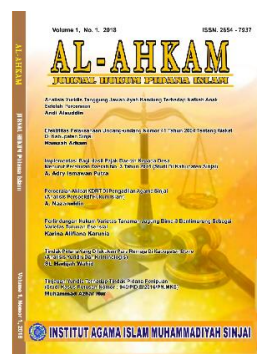

Al-Ahkam

Jurnal Hukum Pidana Islam

Volume 2, No. 2, 2020

ISSN (print) : 2654-7937

ISSN (online) : 2715-0313

Homepage : http://journal.iaimsinjai.ac.id/index.php/al-ahkam/index

Tetapi bila ditinjau dari keseluruhan ayat-ayat riba, seperti al- Baqarah ayat 275 (mengharamkan riba), ayat 276 masih dalam surat al-Baqarah menyatakan bahwa Allah menghapus keberkahan riba dan demikian pula dalam surat al-Baqarah ayat 278-279, yang menegaskan tentang pelarangan riba, meskipun sedikit pengambilan bunga (tambahan) tersebut tetap dilarang, hal ini menunjukkan bahwa tujuan ideal al-Qur'an adalah menghapus riba sampai membersihkan unsur- unsurnya.

Dalam surat al-Baqarah ayat 278-279 menjelaskan secara tegas terhadap pelarangan pelaku riba:

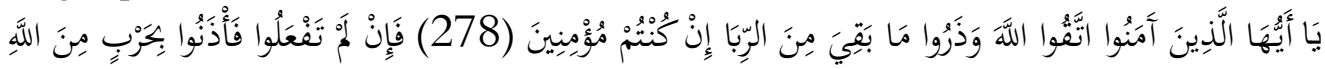

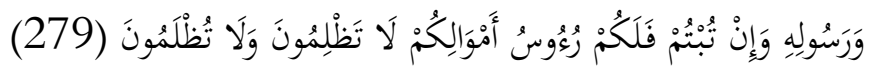

Terjemahannya: "Hai orang-orang beriman, bertakwalah pada Allah dan tinggalkan sisa riba jika kamu orang-orang yang beriman. Maka jika kamu tidak melaksanakan (apa yang diperintahkan ini) maka ketahuilah, bahwa akan terjadi perang dahsyat dari Allah dan RosulNya dan jika kamu bertaubat maka bagi kamu pokok harta kamu, kamu tidak dianiaya dan tidak (pula) dianiaya".

Ayat ini Allah menganjurkan hamba-Nya yang beriman supaya menjaga dirimu dalam taqwa, dalam tiap gerak, langkah, tutur kata dan amal perbuatan supaya benar-benar dijalan Allah dan tinggalkan sisa hartamu (riba) yang masih ada ditangan orang, selebihnya dari apa yang kalian berikan kepada mereka, jika kalian benar-benar beriman, percaya syari'at tuntunan Allah dan melakukan segala yang diridha'i-Nya dan menjauh dari semua yang dilarang dan dimurka-Nya.

Ahli-ahli tafsir menyebut di sini adalah kejadian pada Bani Amr bin Umar dari suku Tsaqief dan Bani al-Mughirah dari suku Makhzum, ketika di masa Jahiliyah terjadi hutang piutang riba, kemudian ketika Islam datang, suku Tsaqief akan menuntut kekurangan riba yang belum dilunasi tetapi banul Mughirah berkata, "Kami tidak akan membayar riba dalam Islam, maka gubernur Mekkah Attab bin Usaid menulis surat kepada Rasulullah SAW, surat tersebut berisi mengenai kejadian hutang piutang antara Bani Amr bin Umar dari suku Tsaqief dengan Bani Mughirah dari suku Makhzum, maka turunlah ayat 278- 279 dari surat al- Baqarah ini, maka Bani Amr bin Umar berkata, "Kami tobat kepada Allah dan membiarkan sisa riba itu semuanya (Salim Bahreisy dan Said Bahriesy.hlm. 506- 507).

Tampaknya pelarangan riba dalam al-Qur'an datang secara bertahap seperti larangan minum khamar. Dalam surat al-baqarah merupakan ayat riba yang terakhir dan para ahli hukum Islam dan ahli tafsir tidak ada yang membantahnya. Berbagai riwayat yang dikutip oleh mufassir ketika mereka menjelaskan sebab turunnya kelompok ayat ini menyebutkan bahwa ayat tersebut merupakan ketegasan atas praktek riba yang ditampilkan antara penduduk Makkah dan penduduk Taif.

Pengharaman riba menempuh metode secara gredual (step by step). Metode ini ditempuh agar tidak mengagetkan mereka yang telah biasa melakukan perbuatan riba dengan maksud membimbing manusia secara mudah dan lemah lembut untuk mengalihkan kebiasaan mereka yang telah mengakar, mendarah daging yang melekat dalam kehidupan perekonomian jahiliyah. Ayat yang diturunkan pertama dilakukan secara temporer yang pada akhirnya ditetapkan secara permanen. Dalam Alquran, riba disebut delapan kali dalam empat surah yang berbeda, yakni satu kali dalam ayat 39 surah al-Rum, satu kali dalam ayat 161 surah al-Nisa, satu kali dalam ayat 130 surah Ali Imran, tiga kali dalam ayat 275 surah al-Baqarah, satu kali dalam ayat 276 surah al-Baqarah, dan satu kali dalam ayat 278 


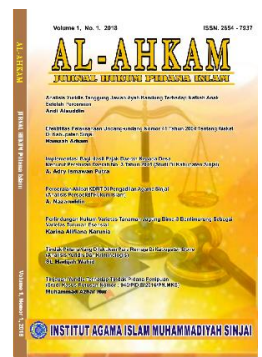

surah al-Baqarah. Keempat surah tersebut secara kronologis menggambarkan empat tahapan pengharaman riba dalam al-Quran.

Tahap pertama: Dalam surat Ar-Rum ayat 39 Allah menyatakan secara nasihat bahwa Allah tidak menyenangi orang yang melakukan riba. Dan untuk mendapatkan hidayah Allah ialah dengan menjauhkan riba. Di sini, Allah menolak anggapan bahwa pinjaman riba yang mereka anggap untuk menolong manusia merupakan cara untuk mendekatkan diri kepada Allah. Berbeda dengan harta yang dikeluarkan untuk zakat, Allah akan memberikan barakah-Nya dan melipat gandakan pahalaNya. Pada ayat ini Allah Swt tidaklah menyatakan larangan dan belum mengharamkannya.

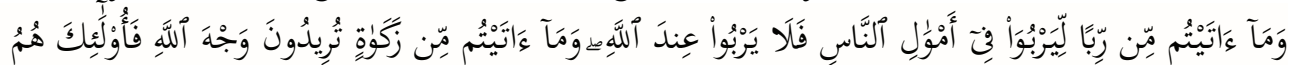

$$
\begin{aligned}
& \text { ألْمُضْعِفُونَ }
\end{aligned}
$$

Terjemahnya: "Dan sesuatu riba (tambahan) yang kamu berikan agar dia bertambah pada harta manusia, maka riba itu tidak menambah pada sisi Allah. Dan apa yang kamu berikan berupa zakat yang kamu maksudkan untuk mencapai keridhaan Allah, maka (yang berbuat demikian) itulah orang-orang yang melipat gandakan (pahalanya)".

Mayoritas ahli tafsir (jumhûr al-mufassirîn) berpendapat bahwa yang dimaksud dengan riba pada ayat tersebut adalah suatu bentuk pemberian (al'athiyyah) yang disampaikan seseorang kepada orang lain bukan dengan tujuan untuk menggapai rida Allah Swt., tetapi hanya sekadar untuk mendapatkan imbalan duniawi semata. Karena itu, pelakunya tidak akan memperoleh pahala dari Allah Swt. atas pemberiannya itu. Hal ini berbeda dengan zakat, yang ketika menunaikannya, para pelakunya, hanya ingin mendapatkan ridha Allah Swt (Abd al-'Azhîm Jalâl Abû Zayd, hlm. 70). Namun demikian, meskipun pemberian sesuatu dari seseorang dengan motif untuk menggapai sesuatu yang lebih banyak (al-ziyâdah) termasuk dalam kategori riba, ia tetap boleh diterima.

Contoh pemberian semacam itu, antara lain, adalah ucapan salam yang disampaikan seseorang kepada orang lain. Kendatipun halal bagi orang lain, khusus untuk Nabi Muhammad Saw., menurut al-Qurthubî, riba semacam itu tetap merupakan sebuah tindakan yang haram beliau lakukan. Untuk melegitimasi pendapat tersebut, al-Qurthubî menyampaikan dalil berupa firman Allah dalam ayat 6 surah al-Muddatstsir yang berbunyi sebagai berikut:

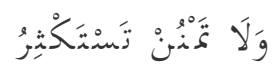

Terjemahnya: "Dan janganlah kamu memberi (dengan maksud) memperoleh (balasan) yang lebih banyak".

Tahap kedua: Pada tahap kedua, Allah menurunkan surat An-Nisa' ayat 160- 162. Riba digambarkan sebagai sesuatu pekerjaan yang dhalim dan batil. Dalam ayat ini Allah menceritakan balasan siksa bagi kaum Yahudi yang melakukannya. Ayat ini juga menggambarkan Allah lebih tegas lagi tentang riba melalui riwayat orang Yahudi walaupun tidak terus terang menyatakan larangan bagi orang Islam. Tetapi ayat ini telah membangkitkan perhatian dan kesiapan untuk menerima pelarangan riba. Ayat ini menegaskan bahwa pelarangan riba sudah pernah terdapat dalam agama Yahudi. Ini memberikan isyarat bahwa akan turun ayat berikutnya yang akan menyatakan pengharaman riba bagi kaum Muslim. 


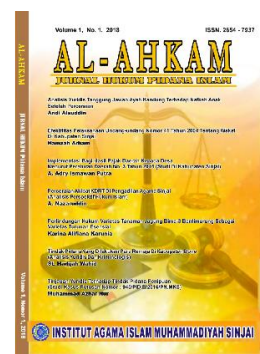

Al-Ahkam

Jurnal Hukum Pidana Islam

Volume 2, No. 2, 2020

ISSN (print) : 2654-7937

ISSN (online) : 2715-0313

Homepage : http://journal.iaimsinjai.ac.id/index.php/al-ahkam/index

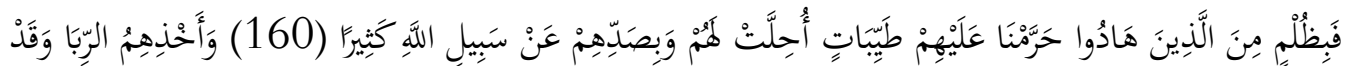

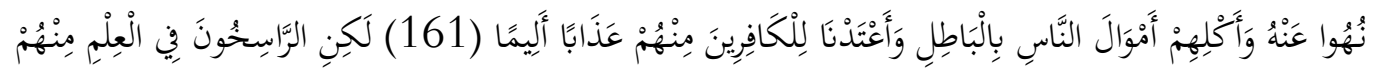

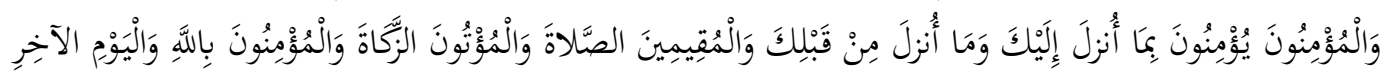

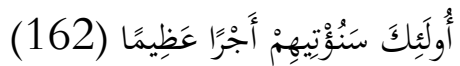

Terjemahnya: "Maka disebabkan kezaliman orang-orang Yahudi, Kami haramkan atas mereka (memakan makanan) yang baik-baik (yang dahulunya) dihalalkan bagi mereka, karena mereka banyak menghalangi (manusia) dari jalan Allah, disebabkan mereka memakan riba. padahal sesungguhnya mereka telah dilarang darinya, dan karena mereka memakan harta orang dengan jalan yang batil. Kami telah menyediakan untuk orangorang yang kafir di antara mereka itu siksa yang pedih. Tetapi orang-orang yang mendalam ilmunya di antara mereka dan orang-orang mukmin, mereka beriman kepada apa yang telah diturunkan kepadamu (Al-Qur'an), dan apa yang telah diturunkan sebelummu dan orang-orang yang mendirikan salat, menunaikan zakat, dan yang beriman kepada Allah dan hari kemudian. Orang-orang itulah yang akan Kami berikan kepada mereka pahala yang besar".

Ayat tersebut menjelaskan tentang adanya semacam hukuman Tuhan terhadap kaum Yahudi, sehingga mereka tidak diperbolehkan lagi mengonsumsi beberapa jenis makanan tertentu yang semula dihalalkan bagi mereka. Menurut Ibn Katsîr, pengharaman yang dimaksud pada ayat tersebut terjadi dalam dua kategori. Pertama, pengharaman secara qadariyyah, yakni pengharaman yang bersumber dari ulah mereka sendiri yang melakukan penggubahan terhadap makanan-makanan halal tertentu yang semula dihalalkan Allah menjadi haram menurut versi mereka sendiri, seperti daging dan susu onta. Tindakan tersebut tentu saja berimplikasi pada timbulnya kesulitan atas diri mereka sendiri. Karena ulah mereka sendiri tersebut, kemudian Allah Swt. melakukan pengharaman dalam kategori Kedua, yakni pengharaman secara syar'iyyah yaitu pengharaman beberapa jenis makanan tertentu yang semula dihalalkan bagi mereka yang sengaja ditetapkan-Nya dalam kitab Taurat.

Tahap ketiga: Dalam surat Ali Imran ayat 130, Allah tidak mengharamkan riba secara tuntas, tetapi melarang dalam bentuk lipat ganda. Hal ini menggambarkan kebijaksanaan Allah yang melarang sesuatu yang telah mendarah daging, mengakar pada masyarakat sejak zaman jahiliyah dahulu, sedikit demi sedikit, sehingga perasaan mereka yang telah biasa melakukan riba siap menerimanya.

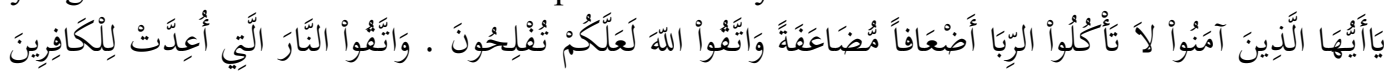

Terjemahnya: "Hai orang-orang yang beriman, janganlah kamu memakan riba dengan berlipat ganda dan bertakwalah kamu kepada Allah supaya kamu mendapat keberuntungan. Peliharalah dirimu dari api neraka, yang disediakan untuk orang-orang yang kafir."

Tentang sebab turunnya ayat di atas, Mujahid mengatakan, "Orang-orang Arab sering mengadakan transaksi jual beli tidak tunai. Jika jatuh tempo sudah tiba dan pihak yang berhutang belum mampu melunasi maka nanti ada penundaan waktu pembayaran dengan kompensasi jumlah uang yang harus dibayarkan juga menjadi bertambah."

Menurut Sayyid Quthb, penggalan ayat 130 dalam surah al-Imran yang berbunyi: merupakan sebuah sifat yang lazim melekat pada riba. Karena itu, meskipun ditetapkan dalam kadar yang sedikit saja, secara natural seiring bertambahnya waktu, riba yang sedikit itu lama-kelamaan pasti akan berubah menjadi berlipat ganda juga (Sayyid 


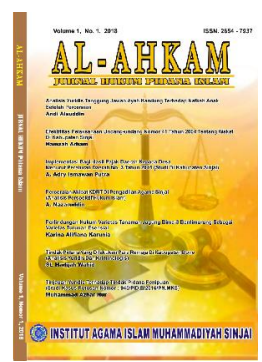

\section{Al-Ahkam}

Jurnal Hukum Pidana Islam

Volume 2, No. 2, 2020

ISSN (print) : 2654-7937

ISSN (online) : 2715-0313

Homepage : $\underline{\text { http://journal.iaimsinjai.ac.id/index.php/al-ahkam/index }}$

Quthhb. h. 74). Bila pendapat Sayyid Quthb ini diterima, maka riba tetap haram hukumnya, baik dalam kadar yang sedikit maupun dalam kadar yang berlipat ganda.

Tahap keempat: Turun surat al-Baqarah ayat 275-279 yang isinya tentang pelarangan riba secara tegas, jelas, pasti, tuntas, dan mutlak mengharamannya dalam berbagai bentuknya, dan tidak dibedakan besar kecilnya. Bagi yang melakukan riba telah melakukan kriminalisasi. Dalam ayat tersebut jika ditemukan melakukan kriminalisasi, maka akan diperangi oleh Allah SWT dan Rasul-Nya.

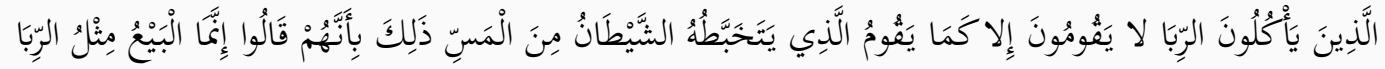

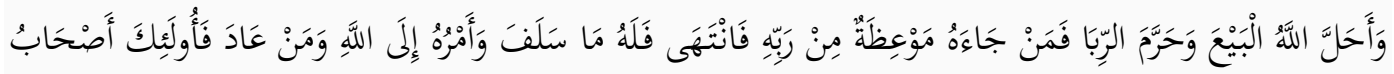

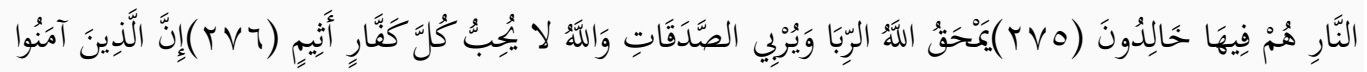

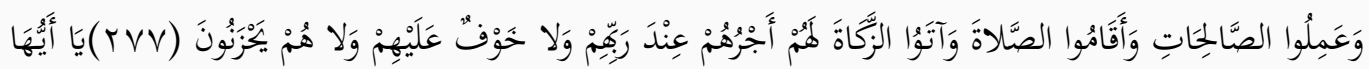

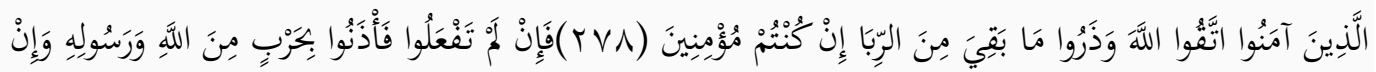

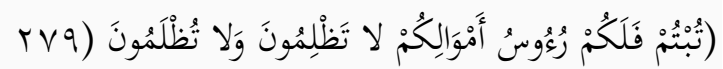

Terjemahnya: "Orang-orang yang Makan (mengambil) riba tidak dapat berdiri melainkan seperti berdirinya orang yang kemasukan syaitan lantaran (tekanan) penyakit gila. Keadaan mereka yang demikian itu, adalah disebabkan mereka berkata (berpendapat), Sesungguhnya jual beli itu sama dengan riba, Padahal Allah telah menghalalkan jual beli dan mengharamkan riba. orang-orang yang telah sampai kepadanya larangan dari Tuhannya, lalu terus berhenti (dari mengambil riba), Maka baginya apa yang telah diambilnya dahulu (sebelum datang larangan); dan urusannya (terserah) kepada Allah. orang yang kembali (mengambil riba), Maka orang itu adalah penghuni-penghuni neraka; mereka kekal di dalamnya. Allah memusnahkan Riba dan menyuburkan sedekah. dan Allah tidak menyukai Setiap orang yang tetap dalam kekafiran, dan selalu berbuat dosa. Sesungguhnya orang-orang yang beriman, mengerjakan amal saleh, mendirikan shalat dan menunaikan zakat, mereka mendapat pahala di sisi Tuhannya. tidak ada kekhawatiran terhadap mereka dan tidak (pula) mereka bersedih hati. Hai orang-orang yang beriman, bertakwalah kepada Allah dan tinggalkan sisa Riba (yang belum dipungut) jika kamu orang-orang yang beriman. Maka jika kamu tidak mengerjakan (meninggalkan sisa riba), Maka ketahuilah, bahwa Allah dan Rasul-Nya akan memerangimu. dan jika kamu bertaubat (dari pengambilan riba), Maka bagimupokok hartamu; kamu tidak Menganiaya dan tidak (pula) dianiaya."

Penafsirannya ayat 275 surah al-Baqarah adalah sebagai berikut; "Orang orang yang memakan riba tiada berdiri, melainkan sebagai berdiri orang yang dibanting syaithan (kemasukan syaithan). Yang demikian itu disebabkan perkataan mereka: "hanya saja jual beli itu, sama dengan riba". Bagaimana mereka menyamakan jual beli dengan riba padahal Allah telah menghalalkan jual beli dan mengharamkan riba, Allah tidak menyamakan hukum keduanya. Maka barang siapa datang kepadanya pengajaran dari Tuhannya, lalu berhenti, maka menjadi kepunyaannya apa yang telah diambil. Dan urusannya terserah kepada Allah. dan barangsiapa kembali lagi memakan riba maka itulah penghuni penghuni neraka, mereka kekal di dalamnya (Hasbi ash Shiddieqy, hlm .276)

Penafsirannya ayat 276 surah al-Baqarah yaitu "Allah membinasakan riba dan menyuburkan sedekah16 dan Allah tiada menyukai orang yang sangat mengingkari nikmat Allah dan terus menerus mengerjakan dosa (Hasbi ash Shiddieqy, hlm .276). Ayat ini menandakan bahwa memakan riba adalah perbuatan orang kafir. 


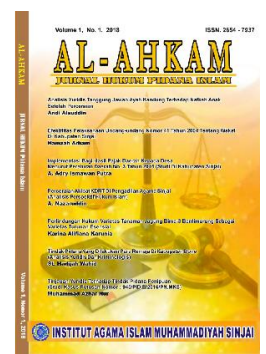

Al-Ahkam

Jurnal Hukum Pidana Islam

Volume 2, No. 2, 2020

ISSN (print) : 2654-7937

ISSN (online) : 2715-0313

Homepage : http://journal.iaimsinjai.ac.id/index.php/al-ahkam/index

Penafsirannya ayat 278 surah al-Baqarah adalah hai orang orang yang telah beriman bertaqwalah kepada Allah dan tinggalkanlah sisa riba yang masih ada pada langganan langgananmu jika kamu memang orang orang yang beriman (Hasbi ash Shiddieqy, hlm .276).

Penafsirannya ayat 279 surah al-Baqarah adalah jika kamu tiada mengerjakannaya ( jika kamu tiada meninggalkannya), maka ketahiulah bahwa kamu diperangi (dimarahi) Allah dan RasulNya. Dan jika kamu bertaubat dari memakan riba maka bagimu pokok pokok hartamu; tiada boleh kamu menganiaya dan di aniaya (Hasbi ash Shiddieqy, hlm .276).

Ayat 278-279 surah al-Baqarah diturunkan sehubungan dengan pengaduan Bani Mughirah kepada Gubernur kota Mekkah Atab bin Usaid setelah terbukanya kota Mekkah tentang utang-utang yang dilakukan dengan riba sebelum turunnya ayat yang mengharamkan riba. Bani Mughirah mengutangkan harta kekayaan kepada Bani Amr bin Auf dari penduduk Tsaqif. Bani Mughirah berkata kepada Atab bin Usaid: "Kami adalah segolongan yang paling menderita lantaran dihapusnya riba. Kami ditagih riba oleh orang lain, sedangkan kami tidak mau menerima riba lagi. Karena taat kepada peraturan Allah Swt yang menghapus riba". Bani Amr bin Auf berkata: "Kami minta penyelesaian masalah tagihan riba kami". Oleh sebab itu gubernur Mekkah Atab bin Usaid mengirim surat kepada Rasulullah Saw yang isinya melaporkan kejadian tersebut. Surat itu dijawab Rasulullah Saw setelah turunnya ayat ke 278 dan 279 ini (Ahmad Mudzab Mahali, Asbabun Nuzul, (Jakarta: Rajawali, 1989), h. 134).

Hukum riba adalah haram. Riba tidak sama dengan jual beli, Allah menghalalkan jual beli dan mengharamkan riba. Apabila telah datang peringatan Allah tentang haramnya riba, maka harus berhenti memakan riba dan dilarang melakukannya. Mengenai riba yang dilakukan sebelum datangnya peringatan Allah tentang haramnya riba, maka urusan tersebut terserah Allah Swt. Allah memusnahkan riba dan menyuburkan sedekah dengan melipatgandakan pahalanya. Allah tidak menyukai terhadap orang yang mempertahankan kekafirannya setelah datangnya petunjuk dari Allah. Orang-orang yang beriman adalalah mereka yang melakukan amal shalih yang diperintahkan Allah Ta'ala dan juga amal sunnah yang dianjurkan Allah Ta'ala. Mereka mengerjakan shalat fardhu dengan rukun-rukunnya, juga menunaikan sunnah-sunnahnya, mereka menunaikan zakat wajib dari harta mereka. masayarakat yang beriman dan beramal shalih, tidak mungkin menimbulkan riba. Allah menyuruh untuk meninggalkan sisa-sisa riba setelah datangnya petunjuk Allah tentang larangan melakukan riba.

\section{d. Pandangan kaum Modern}

Kaum modernis memandang riba lebih menekankan pada aspek moralitas atas pelarangannya, dan "menomorduakan" "legal-form" atas riba, seperti yang ditafsirkan dalam fiqh. Para kaum modernis adalah Fazlur Rahman (1964), Muhammad Asad (1984), Sa'id al-Najjar (1989), dan Abd al-Mun'im al-Namir (1989).

Menurut Muhammad Asad: "Garis besarnya, kekejian riba (dalam arti di mana istilah digunakan dalam al-Qur'an dan dalam banyak ucapan Nabi SAW) terkait dengan keuntungan-keuntungan yang diperoleh melalui pinjaman- pinjaman berbunga yang mengandung eksploitasi atas orang-orang yang berekonomi lemah orang-orang kuat dan kaya...dengan menyimpan definisi ini di dalam benak kita menyadari bahwa persolan mengenai jenis transaksi keuangan mana yang jatuh ke dalam kategori riba, pada akhirnya, adalah persoalan moralitas yang sangat terkai dengan motivasi sosio-ekonomi yang mendasari hubungan timbal-balik antara si peminjam dan pemberi pinjaman"(Tim Pengembangan Perbankan Syariah Institut Bankir Indonesia. hlm. 39-40). 


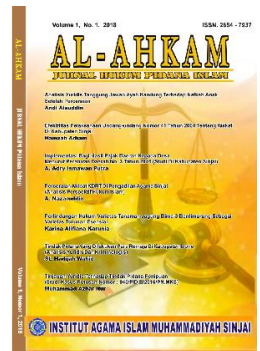

Al-Ahkam

Jurnall Hukum Pidana Islam

Volume 2, No. 2, 2020

ISSN (print) : 2654-7937

ISSN (online) : 2715-0313

Homepage : $\underline{\text { http://journal.iaimsinjai.ac.id/index.php/al-ahkam/index }}$

Menurut pemikir modern yang lain adalah Abdullah Yusuf Ali, beliau mendefiniskan riba adalah: "Tidak dapat disangsikan lagi tentang pelarangan riba. Pandangan yang biasa saya terima seakan-akan menjelaskan bahwa tidak sepantasnya memperoleh keuntungan dengan menempuh jalan perdagangan yang terlarang, di antaranya dengan pinjam meminjam terhadap emas dan perak serta kebutuhan bahan makanan meliputi gandum, gerst (seperti gandum yang dipakai dalam pembuatan bir), kurma, dan garam. Menurut pandangan saya, seharusnya larangan ini mencakup segala macam bentuk pengambilan keuntungan yang dilakukan secara berlebih-lebihan dari seluruh jenis komoditi, kecuali melarang pinjaman kredit ekonomi yang merupakan produk perbankan modern" (Abdullah Saeed. hlm. 42).

Sedangkan Fazlur Rahman berpendapat bahwa riba: "Mayoritas kaum muslim yang bermaksud baik dengan bijaksana tetap berpegang teguh pada keimanannya, menytakan bahwa al-Qur'an melarang seluruh bunga bank. (menanggapi penjelasan tersebut) sedih rasanya pemahaman yang mereka dapatkan dengan cara mengabaikan bentuk riba yang bagaimanakah yang menurut sejarah dilarang, mengapa al-Qur'an mencelanya sebagai perbuatan keji dan kejam mengapa menganggapnya sebagai tindakan eksploitatif serta melarangnya, dan apa sebenarnya fungsi bunga bank pada saat ini”.

Bagi kaum modernis tampak dengan jelas bahwa apa yang diharamkan adalah adanya eksploitasi atas orang-orang miskin, bukan pada konsep bunga itu sendiri (legalform) menurut hokum Islam, apa yang diharamkan adalah tipe peminjaman yang berusaha mengambil untung dari penderitaan orang lain.

\section{Simpulan}

Dari uraian di atas, maka dapat disimpulkan bahwa riba merupakan kegiatan eksploitasi dan tidak memakai konsep etika atau moralitas. Allah mengharamkan transaksi yang mengandung unsur ribawi, hal ini disebabkan mendzalimi orang lain dan adanya unsur ketidakadilan (unjustice).

Riba disamaartikan dengan rente yaitu pengambilan tambahan dari harta pokok atau modal secara batil, karena sama-sama mengandung bunga (interest) uang, maka hukumnya sama pula.

Sejak pra-Islam riba telah dikenal bahkan sering dilakukan dalam kegiatan perekonomian sehari-hari. Pada masa Nabi Muhammad SAW riba mulai dilarang dengan turunnya ayat-ayat al-Qur'an yang menyatakan larangan akan riba, ayat tersebut turun sesuai dengan masa dan periode turunnya ayat sampai ada ayat yang melarangnya secara tegas. Tetapi tidak hanya Islam saja yang melarang pengambilan riba, tetapi agama-agama samawi juga melarang dan mengutuk para pelaku riba.

Secara garis besar riba ada dua yaitu: riba akibat hutang piutang dan riba akibat jual beli. Kaum modernis memandang riba lebih menekankan kepada aspek moralitas, bukan pada aspek legal formalnya, tetapi mereka tidak membolehkan kegiatan pengambilan riba.

Islam mengharamkan riba selain telah tercantum secara tegas dalam al-Qur'an surat al-Baqarah ayat 278-279 yang merupakan ayat terakhir tentang pengharaman riba, juga mengandung unsur eksploitasi. Dalam surat al-Baqarah disebutkan tidak boleh menganiaya dan tidak pula dianiaya, maksudnya adalah tidak boleh melipatgandakan (ad'afan mudhaafan) uang yang telah dihutangkan, juga karena dalam kegiatannya cenderung merugikan orang lain. 


\section{Daftar Pustaka}

Abd al-Azhîm Jalâl Abû Zayd, Fiqh al-Ribâ Dirâsah Muqâranah wa Syâmilah li Tathbîqât alMu'ashirah, Bayrût: Mu'assasah al-Risâlah, 1425 H/2004M, h. 70

Abdul Hadi, Abu Sura'i. Bunga Bank dalam Islam, alih Bahasa M. Thalib. Surabaya: AlUkhlas, 1993.

Abū Zahrah, Muhammad, Buhūsu fi al-Ribā, cet.1, Bairut: Dār al-Buhus al- Ilmīyah, 1399 H/ $1980 \mathrm{M}$.

Hendi Suhendi, Fiqih muamalah, Jakarta: PT. Raja GraFindo Persada, 2002, h. 61-62 dan juga lihat dalam Enseklopedi Fiqih Muamalah, Dalam Pandangan Empat Madzhab, terj. Miftahul Khairi, Yogyakarta: Penerbit Maktabah al-Hanif, 2004, h. 109-110

Lubis, Suhrawardi K. Hukum ekonomi Islam. Jakarta: Sinar Grafika, 2004.

Maududi, Syaekh Abul A'la, Al, Berbicara tentang Bunga dan riba, alih bahasa Isnando. Jakarta: Pustaka Qalami, 2003.

Muhammad, dan R. Lukman fauroni. Visi al-Qur'an tentang Etika dan Bisnis, Jakarta: Salemba Diniyah, 2002.

Muhammad, Manajemen bank Syariah. Yogyakarta: Unit Penerbit dan Percetakan (UPP) AMP YKPN, 2002.

Nausiton, Khoiruddin. Riba dan Poligami, Sebuah Studi atas Pemikiran Muhammad Abduh, cet. I. Yogyakarta: Pustaka Pelajar bekerjasama dengan Academia, 1996.

Perwaatmadja, Karnaen. Apakah Bunga sama dengan Riba?, Kertas Kerja Seminar Ekonomi Islam. Jakarta: LPPBS, 1997.

Sayyid Quthhb, Fî Zhilâl al-Qur'ân, (t.tp: Dâr al-Fikr, t.th), Jilid IV, h. 74.

Undang-undang Perbankan. Undang-undang No. 10 Th 1998 tentang Perubahan Undangundang nomor 7 tahun 1992 tentang perbankan. Jakarta: sinar Grafika, 2005 Abdullah al-Mushlih,Fikih Ekonomi Keuangan Islam. cet. I, Jakarta: Darul Haq, 2004, h. 89-90. 